\title{
Potensi Aliran Permukaan dan Sedimentasi pada Drainase Alami Permukiman Pengungsi Erupsi Gunung Sinabung di Siosar, Kabupaten Karo
}

\author{
Nius Abdi Ginting ${ }^{1 *}$, Rauf $^{2}$, Delvian $^{3}$ \\ ${ }^{1,3}$ Program Studi Pengelolaan Sumberdaya Alam dan Lingkungan, Universitas Sumatera Utara \\ ${ }^{2}$ Fakultas Kehutanan, Universitas Sumatera Utara \\ *Koresponden email: news_gs@yahoo.com
}

Diterima: 30 Oktober 2021

Disetujui: 7 Februari 2022

\begin{abstract}
Transformation from forest ecosystem to be residential and farming ecosystems generally causes changes and damages due to open land surface and groundwater run off which can decrease organic substances in that area. The research employs a survey method by comparing Watershed with forest, part of forest, and part of settlement as land covering and settlement with topographic boundaries in order to estimate the potency of groundwater run off surface. Primary data are collected by measuring discharge in field and measuring the parameter of water quality. Secondary data are collected from geographical position, history of Siosar forest, digital RBI map, meteorological data, and population statistic data. The result of research shows that deforestation for settlement increases water discharge of surface runoff and sedimentation especially in the rainy season. The quality of water in the forest area is relatively good whereas the quality of water in settlement is slightly polluted.
\end{abstract}

Keywords: potential of surface runoff, sedimentation, drainage, Mount Sinabung, refugee

\begin{abstract}
Abstrak
Transformasi alih fungsi ekosistem hutan menjadi areal ekosistem permukiman dan areal pertanian pada umumnya akan mengakibatkan perubahan dan kerusakan akibat permukaan tanah yang terbuka. Limpasan air menyebabkan menurunnya kandungan bahan organik dan kualitas tanah sehingga perlu diketahui faktorfaktor penyebab dan potensi yang timbul akibat dari aliran permukaan (run off). Penelitian ini menggunakan metode survei dan pendekatan yang digunakan yaitu pendekatan perbandingan DAS dengan tutupan lahan yang berbeda yaitu hutan, sebagian hutan dan sebagian permukiman, serta permukiman dengan batas-batas topografi, untuk memperkirakan potensi limpasan permukaan. Tujuan penelitian ini adalah untuk mengkaji potensi debit aliran permukaan dan debit sedimentasi yang terjadi pada drainase alami di kawasan permukiman pengungsi erupsi Gunung Sinabung Kabupaten Karo. Data primer diperoleh dari data pengukuran debit air di lapangan dan pengukuran parameter kualitas air. Sedangkan data sekunder didapatkan dari letak secara geografis, sejarah kawasan Hutan Siosar, peta RBI digital, data meteorologi, dan data statistik kependudukan. Dari hasil penelitian diketahui bahwa alih fungsi lahan dari hutan menjadi permukiman mengakibatkan peningkatan debit aliran dan sedimentasi terutama pada saat musim hujan. Kondisi kualitas air di kawasan hutan masih relatif sangat terjaga dengan baik, permukiman masih dalam tahap tercemar ringan.
\end{abstract}

Kata Kunci: potensi aliran permukaan (run off), sedimentasi, drainase, Gunung Sinabung, pengungsi

\section{Pendahuluan}

Dampak erupsi Gunung Sinabung di Kabupaten Karo menyebabkan masyarakat seputar lingkar Sinabung sesuai dengan rekomendasi dari Pusat Vulkanologi dan Mitigasi Bencana Geologi (PVMBG) harus direlokasi ke tempat yang lebih aman dalam melanjutkan kehidupan [1]. Dalam rangka penanganan pengungsi korban erupsi Gunung Sinabung, Pemerintah Kabupaten Karo bersama dengan Pemerintah Pusat mengambil kebijakan untuk areal relokasi berada dalam kawasan hutan yaitu pada Areal Penggunaan Lain (APL) Agropolitan Siosar dan Hutan Produksi Siosar [2]. Areal relokasi untuk lahan permukiman dan pertanian berada dalam kawasan Hutan Produksi [3]. Tahapan awal untuk penyiapan areal Agropolitan Siosar adalah land clearing dengan penebangan kayu pada kawasan Hutan Produksi Tetap (HP) maupun sebagian pada Areal Penggunaan Lain (APL) [4]. Penebangan kayu pada areal kawasan hutan menyebabkan adanya dampak lingkungan dan masyarakat di sekitar areal kawasan hutan tersebut [5]. Pemanfaatan lahan yang tidak sesuai dengan peruntukannya dan mengabaikan keseimbangan ekologi 
merupakan masalah penataan penggunaan ruang yang tengah menjadi perhatian di Indonesia [6]. Ketidaksesuaian tersebut menyebabkan kegiatan pemanfaatan lahan menjadi tidak optimal bahkan cenderung merusak lingkungan [7]. Disamping itu, lahan menjadi tidak dapat berfungsi dengan baik sebagai media produksi maupun sebagai media tata air yang dapat didefinisikan sebagai lahan kritis [8]. Lahan kritis dalam jangka panjang dapat mengakibatkan bencana alam seperti banjir, tanah longsor, dan kekeringan [9].

Pertambahan penggunaan lahan dari satu sisi penggunaan menjadi penggunaan yang lainnya merupakan pengertian perubahan penggunaan lahan [10]. Transformasi alih fungsi ekosistem hutan menjadi areal ekosistem permukiman dan areal pertanian pada umumnya akan mengakibatkan perubahan dan kerusakan akibat permukaan tanah yang terbuka dan limpasan air yang menyebabkan menurunnya kandungan bahan organik dan kualitas tanah sehingga perlu diketahui faktor-faktor penyebab dan potensi yang timbul akibat dari aliran permukaan (run off) [11]. Adapun tujuan dari penelitian ini adalah untuk mengkaji potensi debit aliran permukaan di kawasan permukiman pengungsi erupsi Gunung Sinabung Kabupaten Karo dan debit sedimentasi yang terjadi pada drainase alami di kawasan permukiman pengungsi erupsi Gunung Sinabung Kabupaten Karo. Untuk menganalisis kondisi kualitas air tanah di kawasan permukiman pengungsi erupsi Gunung Sinabung Kabupaten Karo [12].

Unsur-unsur paling utama ekosistem Daerah aliran sungai, terdiri dari: hewan, tanah, air, vegetasi, iklim, tanah dan manusia. Gangguan terhadap salah satu komponen ekosistem akan dirasakan oleh komponen lainnya dengan sifat dampak yang berbeda. Keseimbangan ekosistem akan terjamin apabila kondisi hubungan timbal balik antar komponen berjalan dengan baik dan optimal. Kualitas interaksi antar komponen ekosistem terlihat dari kualitas output ekosistem tersebut. Kualitas ekosistem pada DAS secara fisik terlihat dari besarnya gorong-gorong, sedimentasi, erosi, fluktuasi debit, dan produktifitas lahan [3].

Karakteristik fisik DAS berbeda di setiap bagian hulu, tengah dan hilir berdasarkan topografi dan kondisi lerengnya. Secara ekologis, daerah hulu dan hilir merupakan satu kesatuan fungsi hidrologis [5]. Masing-masing bagian tersebut saling berkaitan. Aktivitas dan kegiatan pergantian tata guna lahan di hulu DAS berdampak pada perubahan fluktuasi debit, transpor sedimen, erosi, penurunan kapasitas tampung danau, pendangkalan sungai dan saluran drainase serta meningkatkan resiko banjir.

Pada daerah hulu DAS, sungai-sungai memiliki kemiringan yang terjal. Curah hujan yang tinggi dan kemiringan terjal akan menimbulkan perubahan fluktuasi debit, erosi dan transport sedimen [3]. Jangka waktu debit aliran pada umumnya berlangsung cukup cepat. Pada bagian hulu ditandai dengan adanya erosi di Daerah Aliran Sungai (DAS) maupun erosi akibat longsoran tebing dan penggerusan dasar sungai [1]. Aliran permukaan merupakan sebagian dari air hujan yang mengalir diatas permukaan tanah. Faktor faktor yang mempengaruhi aliran permukaan antara lain yaitu intensitas hujan, lama waktu hujan, kecepatan dan gejolak aliran permukaan, keadaan penutup tanah topografi, jenis tanah, dan faktor lainya.

Sedimen yang dihasilkan oleh proses erosi dan terbawa oleh aliran air akan diendapkan pada suatu tempat yang kecepatan alirannya melambat atau terhenti. Peristiwa pengendapan ini dikenal dengan peristiwa atau proses sedimentasi. Faktor yang mempengaruhi proses sedimentasi adalah debit aliran. Selama aliran rendah angkutan sedimen bisa jadi sedikit sedangkan pada saat aliran tinggi sungai bisa mengangkut muatan sedimen yang tinggi dengan ukuran sedimen dalam batasan yang lebih luas. Salah satu dampak proses sedimentasi di sungai adalah terjadinya pengendapan sedimen di dasar sungai yang menyebabkan naiknya dasar sungai, kemudian menyebabkan tingginya muka air yang menyebabkan sering terjadi banjir yang menimpa lahan-lahan yang tidak dilindungi. Erosi tanah tidak hanya berpengaruh negatif pada lahan terjadi erosi tetapi juga di daerah hilirnya dimana material sedimen diendapkan. Pengendapan sedimen di bangunan-bangunan sipil di daerah hilir berupa waduk, jalur navigasi air dan saluran-saluran drainase [9].

Kegiatan dan segala aktifitas manusia di areal permukiman yang merupakan bagian dari Daerah Aliran Sungai (DAS) meningkatkan/menambah konsentrasi dalam perairan melalui aktifitas membuang limbah ke sungai atau drainase alami dan pemanfaatan lahan lainnya yang dapat meningkatkan sedimentasi dan erosi. Kualitas air ditentukan oleh kandungan sedimen tersuspensi dan bahan kimia yang terlarut di dalam air. Kawasan Siosar berubah fungsi menjadi kawasan permukiman, ini berdampak terhadap perubahan lingkungan yang terjadi. Selain itu, pertambahan penduduk kedepannya membawa konsekuensi terhadap peningkatan kebutuhan air dan menuntut sarana dan prasarana untuk mendukung segala aktivitasnya masyarakat yang akan berdampak pada kualitas air. Peningkatan kepadatan penduduk membawa konsekuensi serius terhadap kualitas air tanah. Hal ini berkaitan langsung dengan volume limbah (terutama limbah rumah tangga) yang dihasilkan. Analisis kualitas air secara kimia untuk mengetahui kandungan-kandungan kimiawi pada air tanah pada kawasan siosar yang berubah fungsi dari kawasan hutan 
menjadi kawasan permukiman antara lain Biochemical Oxygen Demand (BOD), Chemical Oxygen Demand (COD), Fosfat, kesadahan, Magnesium, Kalsium, Natrium, Nikel dan Seng.

Angka BOD merupakan jumlah oksigen yang dibutuhkan oleh mikroorganisme aerobik untuk menguraikan hampir semua zat organik yang terlarut beserta yang tersuspensi di dalam air. Penguraian zat organik merupakan proses alamiah, suatu badan air dicemari oleh zat organik maka selama proses penguraiannya mikroorganisme dapat menghabiskan oksigen terlarut dalam air. Jumlah oksigen yang dibutuhkan oleh mikroorganisme dalam lingkungan air untuk mendegradasi bahan buangan organik dalam air menjadi karbondioksida dan air. Pemecahan bahan organik mempunyai pengertian bahwa bahan buangan organik ini digunakan oleh organisme sebagai bahan makanan dan energinya yang diperoleh dari proses oksidasi. Nilai BOD yang tinggi berdampak pada penurunan oksigen terlarut atau Dissolved Oxygen (DO) karena bakteri yang ada di dalam air akan menghabiskan oksigen terlarut [11]. Secara umum BOD merupakan parameter yang dipakai dalam menentukan pencemaran oleh bahan organik dalam air buangan. BOD sebagai parameter pencemaran perairan berupa bahan organik dan hubungannya dengan penurunan kandungan oksigen terlarut perairan [2].

Nitrogen dan fosfat yang terbawa menuju air permukaan menyebabkan eutrofikasi pada danau, sungai, dan perairan dangkal. Penggunaan limbah organik sebagai pupuk, seperti rabuk (pupuk kandang) dan lumpur pembuangan (sewage sludge), juga menyebabkan akumulasi logam berat dalam tanah. Pestisida, herbisida, dan senyawa agrokimia lainnya (khususnya jenis organoklorin) terbawa angin atau air, dapat menyebabkan peningkatan konsentrasi zat beracun dalam air permukaan dan tanah [15]). Sementara kandungan $\mathrm{Na}$ di dalam tanah biasa dekspresikan dengan sodisitas sebagai bagian dari kation garam total yang biasa diekspresikan dengan salinitas. Salinitas dan sodisitas yang terlalu tinggi dapat berpengaruh buruk bagi tanaman, pertumbuhan tanaman terhambat karena kesulitan pengambilan unsur hara oleh akar. Kandungan Na yang sangat tinggi di dalam tanah akan berakibat buruk bagi sifat fisika tanah karena akan menyebabkan pelarutan liat, masuk ke perairan dapat memperkeruh perairan [7]. Masalah air sadah banyak ditemukan di daerah yang mengandung komposisi kapur atau pada daerah batu gamping. Kondisi tanah yang mengandung batuan gamping menyebabkan tingkat kesadahan air tanahnya relatif tinggi (keras). Air tanah di daerah batuan gamping mengandung ion-ion $\mathrm{Ca}$ dan $\mathrm{Mg}$ dalam jumlah yang cukup besar [8].

\section{Metode Penelitian}

Penelitian dilaksanakan pada areal seputaran permukiman Pengungsi Erupsi Gunung Sinabung Siosar [12]. Secara Geografis lokasi penelitian berada pada posisi $02^{0} 56^{\prime} 53,2^{\prime \prime}-03^{0} 0{ }^{\prime} 48,6^{\prime \prime}$ Lintang Utara dan $98^{\circ} 26^{\prime} 08,4$ " - 98 29'28,3" Bujur Timur yang berada diantara Gunung Sibuaten dan Gunung Siosar [13].

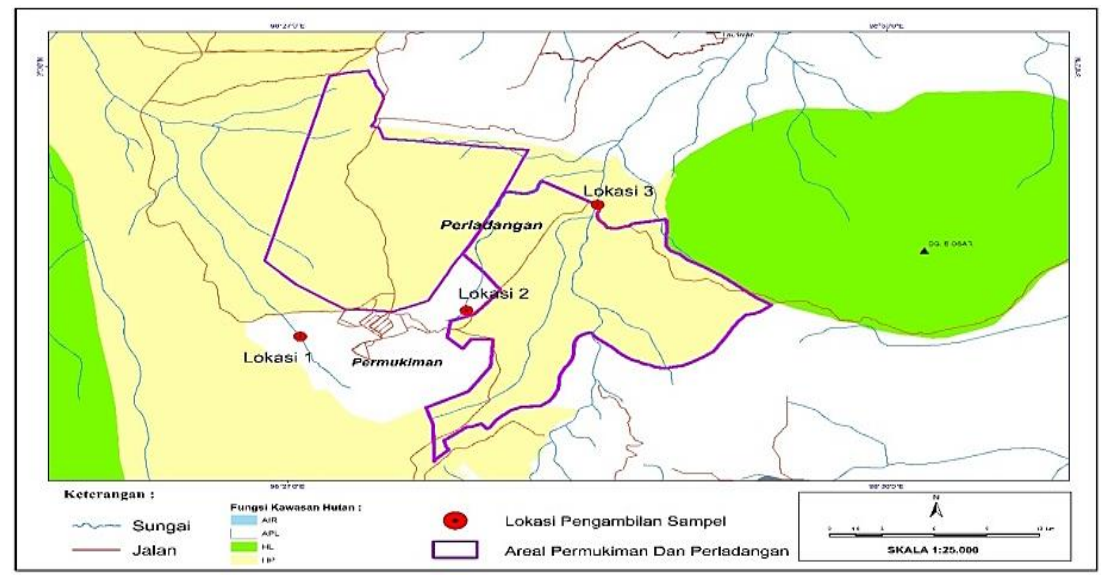

Gambar 1. Peta lokasi penelitian

Sumber: Peta Kawasan Hutan Provinsi Sumatera Utara Sesuai Keputusan Menteri Kehutanan Nomor: SK.579/Menhut-II/2014 Tanggal 24 Juni 2014

Penelitian ini menggunakan metode survei dengan pendekatan yang akan digunakan yaitu pendekatan perbandingan DAS dengan tutupan lahan yang berbeda yaitu hutan, sebagian hutan dan sebagian permukiman, serta permukiman dengan batas-batas topografi, untuk memperkirakan potensi limpasan permukaan. Sumber data yang digunakan dalam penelitian ini terbagi atas 2, yaitu data primer dan data sekunder. Data Primer dalam penelitian ini menggunakan data pengukuran debit air di lapangan dan data pengukuran parameter kualitas air. Data sekunder yang digunakan dalam penelitian ini adalah 
sejarah kawasan hutan Siosar, Peta RBI digital digunakan sebagai dasar dalam pembuatan peta lereng (slope), relief, penggunaan lahan, kepadatan aliran dan penentuan batas administratif, data meteorologi berupa data curah hujan untuk memperkirakan kondisi iklim, distribusi air hujan dan data statistik kependudukan terkait topik penelitian.

Pengamatan dan pengukuran pada penelitian ini dikerjakan melalui beberapa tahapan yaitu pengumpulan data curah hujan berupa data sekunder, besarnya aliran permukaan ditentukan dengan mengukur volume air yang masuk ke dalam tempat penampungan yang telah disiapkan. Pengukuran limpasan permukaan dilakukan dengan menggunakan alat tampung yang terukur. Pengukuran dan pencatatan dilakukan pada hari saat hujan dan saat cerah. Volume air ( $\mathrm{ml}$ ) yang masuk kedalam bak penampungan dikonversikan kedalam satuan besaran aliran permukaan $(\mathrm{mm})$ dengan cara membagi volume air yang tertampung dengan luasan petak percobaan di lapangan sehingga didapatkan besaran aliran permukaan dalam satuan mm. Banyaknya tanah yang terangkut (total) saat aliran permukaan terjadi ditentukan dengan metoda volumetric dengan menimbang berat basah yang tertinggal pada wadah penampung dan mengukur setelah dikeringkan, kemudian hasilnya dikalikan dengan persentase air yang digunakan dan Analisis terhadap mutu/ kualitas air dengan menentukan status kualitas/mutu kualitas air dengan metode indeks pencemaran.

Metode analisis data yang digunakan untuk memprediksikan perkiraan besarnya potensi debit air menggunakan rumus :

$$
\mathrm{Q}=\frac{V}{t}
$$

Dimana:

Q : debit aliran permukaan,

$\mathrm{V}$ : volume

$\mathrm{t} \quad$ : waktu

Sedimen diukur melalui kadar lumpur air pada lokasi DAS yang diperoleh dari hasil Analisa sampler dengan cara Air dimasukkan ke dalam kertas filter dengan mencatat tanggal, volume air, TMA dan lokasi pengambilan sampel, kertas filter dikeringkan, timbang masing-masing sampel, catat tanggal, volume air dan disesuaikan dengan lokasi pengambilan, berat filter isi, berat filter kosong. Berdasarkan tabel nilai skala standar di indeks rezim air pada penelitian Koesnandar dan Sigit (2007) diketahui jika konsentrasi sedimen melayang dikelompokkan ke dalam 5 kategori, yakni sangat baik $(0 \mathrm{mg} / \mathrm{L})$, baik $(0-100 \mathrm{mg} / \mathrm{l})$, sedang $(>100-250 \mathrm{mg} / \mathrm{l})$, jelek $(>250-500 \mathrm{mg} / \mathrm{L})$, dan sangat jelek $(>500 \mathrm{mg} / \mathrm{L})$. Selanjutnya, setelah diperoleh konsentrasi (Cs), maka untuk menghitung debit suspensi adalah sebagai berikut :

$$
\mathrm{Qs}=(86,4 . \text { Cs. Qw })
$$

Keterangan :

$$
\begin{array}{ll}
\text { Qs } & \text { : Debit Suspensi (kg/hari) } \\
\text { Qw } & : \text { Debit Aliran (m³/detik) } \\
\text { Cs } & : \text { Konsentrasi Suspensi } \\
86,4 & : \text { Nilai Konversi }
\end{array}
$$

Pengujian status mutu air dilakukan dengan pengambilan sampling pada saat hujan dan kering sebanyak 3 kali ulangan dan sampel diuji di laboratorium penguji Baristan, Medan. Adapun parameter kimia yang dianalisis di Laboratorium dapat dilihat pada Tabel $\mathbf{1}$.

Tabel 1. Parameter uji kualitas air tanah

\begin{tabular}{lllll}
\hline No. & Parameter & Satuan & $\begin{array}{l}\text { Baku } \\
\text { Mutu }\end{array}$ & Metode Analisis \\
\hline 1. & COD & $\mathrm{mg} / \mathrm{L}$ & 10 & Metode refluks (SNI 6989-73-2009) \\
2. & BOD & $\mathrm{mg} / \mathrm{L}$ & 2 & Metode Winkler dan inkubasi \\
3. & Phospat & $\mathrm{mg} / \mathrm{L}$ & 0.2 & Spektrofotometri \\
4. & Kesadahan $(\mathrm{CaCO} 3)$ & $\mathrm{mg} / \mathrm{L}$ & 500 & SNI 06-6989.12-2004 \\
5. & Magnesium & $\mathrm{mg} / \mathrm{L}$ & 30 & SNI 06-6989.12-2004 \\
6. & Kalsium & $\mathrm{mg} / \mathrm{L}$ & 10 & SNI 06-6989.12-2004 \\
\hline
\end{tabular}




\begin{tabular}{lllll}
\hline No. & Parameter & Satuan & $\begin{array}{l}\text { Baku } \\
\text { Mutu }\end{array}$ & Metode Analisis \\
\hline 7. & Natrium & $\mathrm{mg} / \mathrm{L}$ & 200 & APHA 3500-Na \\
8. & Nikel & $\mathrm{mg} / \mathrm{L}$ & 0.5 & SNI 6989.18-2009 \\
9. & Seng & $\mathrm{mg} / \mathrm{L}$ & 0.05 & SNI 06-2474-1991 \\
\hline
\end{tabular}

Sumber : Data primer hasil pengamatan dan hasil laboratorium penguji baristan Medan (2020)

Data yang diperoleh dari hasil pemeriksaan kualitas air kemudian dianalisis status kualitas air dengan cara/metode IP (indeks pencemaran) menurut Keputusan Menteri Lingkungan Hidup No. 115 Tahun 2003. Evaluasi terhadap nilai IP dapat dilihat pada Tabel 2.

Tabel 2. Status mutu air dengan Indeks Pencemaran

\begin{tabular}{ll}
\hline Nilai IP & Mutu air \\
\hline $0 \leq \mathrm{P} \mathrm{j} \leq 1,0$ & Sesuai baku mutu (kondisi baik) \\
$1,0<\mathrm{P}<5,0$ & cemar ringan \\
$5,0<\mathrm{P} \mathrm{j} \leq 10$ & cemar sedang \\
$\mathrm{P} \mathrm{j}>10$ & cemar berat \\
\hline
\end{tabular}

Sumber : Kep-MENLH No 115 Tahun 2003

\section{Hasil dan Pembahasan}

Kabupaten Karo memiliki tipe iklim E2. Sesuai klasifikasi Oldman E2 memiliki bulan basah atau musim penghujan lebih dari 3 bulan dan musim kemarau bulan kering berkisar $2-3$ bulan. Menurut Koppen Karo sesuai tipe iklim A dengan curah hujan rata-rata diatas $1.000 \mathrm{~mm} / \mathrm{tahun}$ dan curah hujan merata sepanjang tahun. Jumlah curah hujan sepanjang tahun berkisar antara $1.000 \mathrm{~s} / \mathrm{d} 4.000 \mathrm{~mm} / \mathrm{tahun}$, dimana curah hujan terbesar terjadi pada bulan basah, Agustus s/d Januari dan Maret s/d Mei. Curah hujan yang tinggi di bulan-bulan basah ini dipengaruhi oleh angin Musson Timur yang membawa uap air dari Samudera Pasifik dan Laut Cina Selatan ditambah hujan Zenith dan hujan orografis dari angin passat yang membawa uap air dari Samudera Indonesia dan Danau Toba. Sedangkan pada bulan kering hanya tergantung terhadap hujan zenith dan hujan orografis.

Kabupaten Karo memiliki iklim tropis dan yang terdiri dari dua musim yakni musim hujan dan kemarau. Bulan Agustus merupakan musim hujan pertama sampai bulan Januari dan musim kedua pada bulan Maret sampai bulan Mei, sedangkan musim kering umumnya pada bulan Februari, Juni dan Juli. Suhu udara berkisar antara $15,9^{\circ} \mathrm{C}$ sampai dengan $22,2^{\circ} \mathrm{C}$ dengan kelembaban udara rata-rata setinggi 88,80 persen. Jenis tanah di kawasan relokasi termasuk Andiosols [13], solum tanah dalam, tetapi top soil tipis $(10-20 \mathrm{~cm})$. Bahan induk tanah tufa liparit bersifat masam dan vulkan tua di lapisan bawah. Tanah lapisan atas berwarna hitam dan coklat tua, lapisan bawah merah kekuningan, tekstur lempung liat berpasir sampai liat, dan banyak dijumpai pasir kuarsa. Tanah sangat masam, pH lapisan atas berkisar antara 4,5-5,1 dan lapisan bawah 5,2-5,3. Kandungan $\mathrm{C}$ organik tinggi di lapisan atas dan sedang di lapisan bawah, demikian juga dengan $\mathrm{N}$-total yang tergolong tinggi di lapisan atas dan sedang di lapisan bawah. Kategori tanah tersebut adalah jenis tanah yang cukup peka terhadap erosi.

Pada lokasi penelitian didalam perencanaannya dilaksanakan penebangan seluas $\pm 1.066,55 \mathrm{Ha}$ dengan rincian 896,55 Ha untuk perladangan lahan kering dan 170 Ha untuk Permukiman. Berdasarkan analisis dan digitasi citra lansat 7 liputan tahun 2017, tutupan lahan di areal penelitian berupa pertanian lahan kering seluas $\pm 416 \mathrm{Ha}$, semak belukar $\pm 105 \mathrm{Ha}$ dan hutan tanaman jenis Pinus tersisa $\pm 373 \mathrm{Ha}$ seperti terlihat pada Gambar 2. 


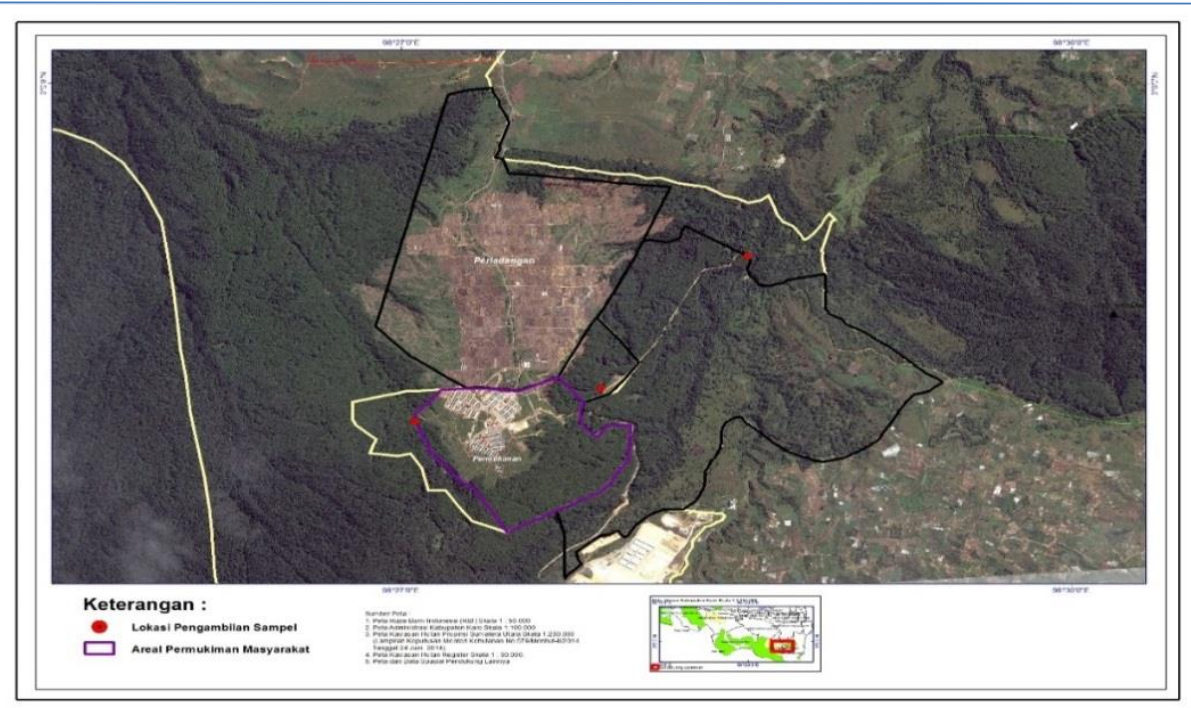

Gambar 2. Peta tutupan lahan

Sumber : Digitasi citra lansat 7 (2017)

Tabel 3 menunjukan daerah tangkapan air di kawasan Siosar dimana kondisi topografi kawasan relokasi Siosar terletak di dataran tinggi atau wilayah pegunungan $(2600 \mathrm{~m}$ dpl $)$, suhu rata-rata harian 18,8 $-19,8^{\circ} \mathrm{C}$, kelembaban udara rata-rata : 84,66 \%, dan curah hujan : $1.000-4.000 \mathrm{~mm} /$ tahun. Berdasarkan hasil kajian karakteristik lahan kawasan relokasi pengungsi erupsi Gunung Sinabung [12] diketahui berada pada 3 kelas kemiringan, yaitu kelas kemiringan lereng 0-8\% (datar hingga landai), 8-15\% (bergelombang) dan $15-25 \%$ dengan areal terluas pada topografi bergelombang. Topografi mempengaruhi debit aliran dan arah aliran dari dataran tinggi ke dataran rendah.

Debit aliran dihitung pada saat hujan dan kering. Tabel 3 ini menunjukan nilai debit air berdasarkan waktu dan volume air yang tertampung dengan kondisi pemanfaatan lahan yang berbeda di kawasan Siosar.

Tabel 3. Hasil pengukuran debit aliran pada beberapa kondisi pemanfaatan/ tutupan lahan

\begin{tabular}{lcccccccc}
\hline \multirow{2}{*}{$\begin{array}{c}\text { Kondisi } \\
\text { pemanfaatan lahan }\end{array}$} & \multicolumn{2}{c}{ Waktu (detik) } & \multicolumn{2}{c}{ Volume (liter) } & \multicolumn{2}{c}{$\begin{array}{c}\text { Debit aliran } \\
\text { (liter/detik) }\end{array}$} & $\begin{array}{c}\text { Debit aliran } \\
\left(\mathrm{m}^{3} / \text { detik }\right)\end{array}$ \\
\cline { 2 - 9 } & Kering & Hujan & Kering & Hujan & Kering & Hujan & Kering & Hujan \\
\hline Areal hutan & 3,06 & 3,37 & 100 & 100 & 27,73 & 29,63 & 0,0277 & 0,0296 \\
$\begin{array}{l}\text { Areal hutan- } \\
\text { permukiman }\end{array}$ & 3,29 & 2,85 & 50 & 50 & 15,18 & 17,51 & 0,0152 & 0,0175 \\
Areal permukiman & 4,64 & 1,21 & 50 & 50 & 10,77 & 41,22 & 0,0108 & 0,0412 \\
\hline
\end{tabular}

Debit air yang terjadi pada setiap titik pengamatan menghasilkan debit air yang berbeda. Debit tertinggi diperoleh pada areal permukiman dengan nilai 41,22 liter/detik atau $0,0412 \mathrm{~m} / \mathrm{detik}$. Ini menunjukan peningkatan debit aliran permukaan pada kawasan permukiman dipengaruhi oleh perubahan fungsi hutan menjadi permukiman. Bertambahnya lahan terbuka dengan hilangnya vegetasi penutup tanah menyebabkan air hujan yang turun langsung ke tanah tanpa melewati tajuk tanaman. Kondisi ini menyebabkan debit aliran yang terjadi di permukiman lebih tinggi. Hutan merupakan vegetasi penutup tanah berfungsi dalam memelihara ketahanan tanah terhadap erosi dan kemampuan tanah dalam meresap air sehingga menahan laju aliran yang terjadi.

Berdasarkan analisis sedimentasi, pada Tabel 4 menggambarkan hasil perhitungan dari beberapa sampel air tanah.

Tabel 4. Hasil pengukuran sedimentasi pada masing-masing lokasi penelitian

\begin{tabular}{lcccccc}
\hline \multirow{2}{*}{$\begin{array}{c}\text { Kondisi pemanfaatan } \\
\text { lahan }\end{array}$} & \multicolumn{2}{c}{$\begin{array}{c}\text { Berat Suspensi rata-rata } \\
\text { (gram) }\end{array}$} & $\begin{array}{c}\text { Konsentrasi Suspensi } \\
\text { (gram/ml) }\end{array}$ & \multicolumn{2}{c}{ Debit suspensi (Kg/hari) } \\
\cline { 2 - 7 } & Kering & Hujan & Kering & Hujan & Kering & Hujan \\
\hline Areal hutan & 0,14 & 0,73 & 0,0014 & 0,0073 & - & - \\
Areal hutan- & 0,07 & 1,04 & 0,0014 & 0,0104 & - & - \\
permukiman & 0,32 & 2,42 & 0,0032 & 0,0242 & - & - \\
Areal permukiman & &
\end{tabular}

Sumber : Data primer hasil pengamatan (2020) 
Dari hasil pengukuran sedimentasi pada Tabel 4 diketahui debit suspensi tertinggi berada pada pemanfaatan lahan permukiman. Kondisi ini disebabkan oleh curah hujan yang relatif tinggi, sehingga menyebabkan suspensi yang cukup tinggi terutama pada lahan terbuka. Hal ini akan menyebabkan sedimentasi yang terangkut semakin besar dan menyebabkan kekeruhan.

Curah hujan yang relatif tinggi dan penggunaan lahan yang tidak seimbang menjadi penyebab terjadinya sedimentasi. Kecepatan aliran sungai mempengaruhi laju transport sedimen terutama sedimen melayang. Menurut penelitian [14], dinyatakan jika volume debit air tinggi maka sedimen melayang yang terukur juga ikut meningkat. Berdasarkan analisis kualitas air, hasil penelitian yang dilakukan pada musim kemarau dan hujan dapat diketahui pada Tabel 5.

Tabel 5. Hasil analisis kualitas air sungai

\begin{tabular}{|c|c|c|c|c|c|c|c|}
\hline \multirow{3}{*}{ Parameter } & \multirow{3}{*}{$\begin{array}{l}\text { Baku } \\
\text { mutu }\end{array}$} & \multicolumn{6}{|c|}{ Hasil Uji Kualitas Air } \\
\hline & & \multicolumn{2}{|c|}{ Areal Hutan } & \multicolumn{2}{|c|}{ Hutan-Permukiman } & \multicolumn{2}{|c|}{ Permukiman } \\
\hline & & Kemarau & Hujan & Kemarau & Hujan & Kemarau & Hujan \\
\hline COD & 10 & 7,57 & 7,57 & 7,57 & 26,3 & 86,7 & 94 \\
\hline BOD & 2 & 0,38 & 0,38 & 4,14 & 15,4 & 7,9 & 15,4 \\
\hline Phospat & 0,2 & 0,02 & 0,02 & 0,002 & 0,07 & 0,03 & 0,03 \\
\hline Kesadahan & & & & & & & \\
\hline$(\mathrm{CaCO} 3)$ & 500 & 12,9 & 16,8 & 19,8 & 24,8 & 24,8 & 29,7 \\
\hline Magnesium & 50 & 3,1 & 4,1 & 4,8 & 6 & 6 & 7,2 \\
\hline Kalsium & 10 & 0 & 0 & 0 & 0 & 0 & 0 \\
\hline Natrium & 200 & 2,44 & 3,17 & 2,45 & 2,38 & 3,08 & 2,68 \\
\hline Nikel & 0,5 & 0,009 & 0,009 & 0,009 & 0,009 & 0,006 & 0,009 \\
\hline Seng & 0,05 & 0,001 & 0,0200 & 0,016 & 0,0200 & 0,001 & 0,002 \\
\hline
\end{tabular}

Sumber : Hasil laboratorium Baristan Medan (2020)

Penurunan kualitas air terjadi akibat perubahan fungsi hutan menjadi kawasan permukiman. Dimana vegetasi yang ada, berubah menjadi kawasan permukiman, sehingga menyebabkan inflitrasi berkurang. Beberapa hal yang menyebabkan demikian, karena pada musim hujan debit aliran akan semakin meningkat setelah alih fungsi hutan menjadi permukiman dan pada musim kering debit sungai atau aliran akan cepat berkurang dibandingkan sebelum kondisi awal sebelum perubahan dari hutan ke permukiman.

Setiap parameter menunjukkan hasil parameter kualitas air yang berbeda tergantung kondisi pemanfaatan lahan disekitarnya. Parameter ini menggambarkan bagaimana kondisi kualitas air di setiap daerah penelitian pada musim hujan dan kering. Sesuai Peraturan Pemerintah no. 82 tahun 2001 [17] beberapa parameter kualitas/mutu air tanah melebihi baku mutu yang diizinkan untuk klas I yaitu untuk sebagai sumber air minum. Berdasarkan Tabel 4.6 diperoleh hasil bahwa diantara parameter kimia air tanah, terdapat tiga sampel pada parameter BOD dan COD yang tidak memenuhi standar baku kualitas/mutu standar sebagai air minum. Nilai COD tertinggi berasal dari kawasan permukiman pada musim hujan maupun kering sedangkan nilai BOD tertinggi di kawasan permukiman pada saat hujan sebesar 15,4 mg/L. BOD menggambarkan bahwa limbah organik yang berasal dari permukiman sangat mempengaruhi kondisi kualitas air tanah di penelitian ini. Air tanah tercemar oleh limbah rumah tangga. Nilai BOD yang terukur pada sampel air sungai adalah sebesar $15,4 \mathrm{mg} / \mathrm{L}$.

Konsentrasi Fosfat pada semua titik pengamatan tidak melebihi standar mutu sesuai Peraturan Pemerintah No. 82 Tahun 2001 yaitu sebesar $0,2 \mathrm{mg} / \mathrm{L}$. Nilai tertinggi konsentrasi phosfat terdapat pada titik pertengahan yaitu pemanfaatan lahan hutan dan permukiman pada saat kondisi hujan yaitu sebesar $0,07 \mathrm{mg} / \mathrm{L}$. Konsentrasi phosfat pada titik ini meningkat kemungkinan akibat aktifitas pertanian di sekitar permukiman dimana masyarakat di Siosar membuka lahan untuk bercocok tanam kembali untuk memenuhi kebutuhan hidupnya. Berdasarkan hasil pengukuran kesadahan pada semua sampel air yang diperiksa menunjukkan bahwa keseluruhan sampel masih mempunyai harga jauh di bawah $500 \mathrm{mg} / \mathrm{L}$, sehingga dikategorikan sebagai air lunak yang tidak membutuhkan pengolahan bila akan dikonsumsi sebagai air minum.

Beberapa logam berat khususnya logam berat nikel banyak digunakan dalam berbagai keperluan. Logam berat dalam penelitian ini yaitu Magnesium (Mg), Kalsium (Ca), Natrium (Na), Seng (Zn) dan Nikel (Ni). Dalam konsentrasi yang normal logam-logam tersebut bermanfaat dalam kehidupan. Akan tetapi ketika logam-logam tersebut berada di lingkungan dalam konsentrasi yang tinggi maka akan menjadi racun dan berbahaya bagi kesehatan manusia, hewan, dan tanaman.

Penelitian ini untuk kandungan logam berat semuanya masih memenuhi baku/standar mutu yang telah ditentukan berdasarkan PP No 82 Tahun 2001 untuk Kelas satu. Sedimen tidak hanya mencerminkan kualitas air permukaan, namun juga memberikan informasi yang penting mengenai transpor dan nasib dari 
bahan-bahan pencemar yang memasuki suatu perairan. Kandungan logam dalam sedimen memainkan peranan penting dalam mendeteksi sumber bahan pencemar di sistem perairan tersebut. Berdasarkan hasil analisis yang dilakukan, konsentrasi logam magnesium $(\mathrm{Mg})$ sangat tinggi jika dibandingkan dengan konsentrasi logam-logam lainnya. Konsentrasi logam berat yang ditemukan dalam jumlah besar berikutnya adalah seng (Zn). Konsentrasi logam yang terkandung masih dikatakan baik sebab nilainya jauh di bawah batas baku mutu kualitas air kelas I.

Jika dibandingkan dengan baku kualitas/mutu air berdasarkan PP No 82 Tahun 2001 menyatakan kandungan logam berbahaya dalam semua titik pengamatan masih berada di bawah kadar maksimum yang diperbolehkan. Kondisi status mutu air tanah berdasarkan metode Indeks Pencemaran dimana evaluasi terhadap nilai IP ditentukan berdasarkan Kepmen Negara Lingkungan Hidup Nomor 115 Tahun 2003 pada daerah penelitian dapat dilihat pada Tabel 6.

Tabel 6. Nilai indeks pencemaran dan status mutu air pada pemanfaatan lahan

\begin{tabular}{lllll}
\hline \multirow{2}{*}{ Kondisi Pemanfaatan Lahan } & \multicolumn{2}{c}{ Indeks Pencemaran } & \multicolumn{2}{c}{ Status mutu air } \\
\cline { 2 - 5 } & Kemarau & Hujan & Kemarau & Hujan \\
\hline Areal hutan & 0,5439 & 0,5445 & Baik & Baik \\
Areal hutan-permukiman & 1,8460 & 3,9085 & Tercemar ringan & Tercemar ringan \\
Areal permukiman & 4,1013 & 4,25 & Tercemar ringan & Tercemar ringan \\
\hline
\end{tabular}

Pada dasarnya suatu ekosistem memiliki kemampuan pulih diri (self purification) terhadap adanya masukan bahan pencemar ke perairan. Namun jika pencemaran logamnya dalam jumlah konsentrasi yang tinggi maka dapat menyebabkan peningkatan bahan pencemar di perairan dan akan terakumulasi pada sedimen dan air. Limbah dari aktivitas kegiatan manusia akan mencemari perairan.

Berdasarkan penelitian pada areal hutan, saat musim kering debit air adalah 27,73 liter per detik dan pada musim hujan adalah 29,63 liter per detik, perbedaan debit ini terjadi akibat kondisi curah hujan yang tinggi sehingga mempengaruhi debit aliran yang terjadi di areal hutan. Dalam hal ini perubahan debit di dalam musim kering dan musim hujan relatif hanya dipengaruhi oleh faktor curah hujan. Untuk aliran permukaan hutan dapat berfungsi sebagai filter alami, karena dapat meminimalkan erosi tanah, sedimen di dalam badan tanah dan berperan sebagai penangkap atau saringan polutan air dalam serasah hutan. Nilai sedimentasi sebesar $0,0014 \mathrm{gr} / \mathrm{ml}$ pada musim kering dan $0,0073 \mathrm{gr} / \mathrm{ml}$ pada musim hujan. Nilai ini menggambarkan terjadi perubahan atau peningkatan sedimentasi pada musim kering dan musim hujan, dengan selisih $0,0059 \mathrm{gr} / \mathrm{ml}$. Kondisi musim hujan dan kering pada kawasan hutan perubahan debit tidak terlalu signifikan pada kawasan hutan. Material sedimen suspensi masih belum cukup kuat untuk terangkut oleh aliran, dimana pepohonan dan masih dapat menahan benturan langsung air hujan kepada agregat tanah, dan pada lantai hutan masih terdapat serasah yang masih mampu mengendapkan sedimen sehingga belum banyak terangkut.

Berdasarkan penelitian pada areal Permukiman dan Hutan, saat musim kering debit air adalah 15,18 liter per detik dan pada musim hujan adalah 17,51 Liter per detik, perbedaan debit ini terjadi akibat kondisi curah hujan yang tinggi sehingga mempengaruhi debit aliran yang terjadi di areal hutan. Nilai sedimentasi sebesar $0,0014 \mathrm{~g} / \mathrm{ml}$ pada musim kering dan $0,0104 \mathrm{~g} / \mathrm{ml}$ pada musim hujan. Nilai ini menggambarkan terjadi perubahan atau peningkatan sedimentasi pada musim kering dan musim hujan, dengan selisih $0,0090 \mathrm{~g} / \mathrm{ml}$. Pada saat musim hujan, arus aliran akan semakin cepat yang mempengaruhi produksi sedimen. Hal ini disebabkan oleh faktor lambatnya tanah menangkap air pada sebagian lahan terbuka, sehingga debit aliran permukaan cukup tinggi, dan berkurangnya penahan air berupa vegetasi pada sebagian lahan terbuka. Kondisi status mutu air pada pemanfaatan lahan ini tercemar ringan tetapi dengan nilai indeks pencemaran yang rendah.

Berdasarkan penelitian pada areal permukiman, saat musim kering debit air adalah 10,77 liter per detik dan pada musim hujan adalah 41,22 liter per detik, perbedaan debit ini terjadi akibat kondisi curah hujan yang tinggi sehingga mempengaruhi debit aliran yang terjadi di areal permukiman. Nilai sedimentasi sebesar $0,0032 \mathrm{~g} / \mathrm{ml}$ pada musim kering dan $0,0242 \mathrm{~g} / \mathrm{ml}$ pada musim hujan. Nilai ini menggambarkan terjadi perubahan atau peningkatan sedimentasi pada musim kering dan musim hujan, dengan selisih $0,0304 \mathrm{gr} / \mathrm{ml}$. Hal ini disebabkan karena pada areal permukiman agregat tanah sangat mudah terlepas disebabkan pukulan langsung air hujan ke dalam tanah. Secara umum pada saat musim hujan terjadi peningkatan sedimentasi terutama pada lokasi permukiman. Pada areal lokasi permukiman di Siosar, yang merupakan peralihan fungsi dari kawasan hutan menjadi permukiman, dimana dalam prosesnya terjadi proses perubahan bentuk tanah, maka sangat cepat terjadi pengangkutan sedimentasi. Pada titik ini kondisi status mutu air pada saat hujan dan kering yaitu tercemar ringan dengan nilai indeks pencemaran tertinggi 
dibandingkan pada kedua titik pengamatan yang lainnya. Daerah permukiman yang dibangun di kawasan Siosar sangat mempengaruhi kondisi kualitas air. Meningkatnya tingkat kepadatan penduduk membawa konsekuensi yang sangat serius terhadap kualitas air tanah. Hal ini berkaitan langsung dengan volume limbah (terutama limbah rumah tangga) yang dihasilkan.

\section{Kesimpulan}

Pada areal permukiman untuk musim kering debit air ada peningkatan antara musim kering dan musim hujan sebanyak 73,83 \% dengan status mutu air tercemar ringan. Pada areal sebagian permukiman dan sebagian hutan pada musim kering debit air ada peningkatan debit sebanyak 13,30\% status mutu air tercemar ringan. Pada areal hutan pada musim kering debit air ada peningkatan debit sebanyak $6,1 \%$ serta kondisi status mutu air dalam keadaan baik.

Sedimentasi pada areal hutan terjadi perubahan atau peningkatan sedimentasi pada musim kering dan musim hujan, dengan selisih $0,0059 \mathrm{gr} / \mathrm{ml}$. Sedimentasi pada areal hutan-permukiman terjadi perubahan atau peningkatan sedimentasi pada musim kering dan musim hujan, dengan selisih $0,0090 \mathrm{gr} / \mathrm{ml}$. Sedimentasi pada areal permukiman terjadi perubahan atau peningkatan sedimentasi pada musim kering dan musim hujan, dengan selisih $0,0304 \mathrm{gr} / \mathrm{ml}$. Sedimentasi meningkat pada saat musim hujan pada setiap lokasi.

Kondisi kualitas air di kawasan hutan masih relatif sangat terjaga dengan baik, permukiman masih dalam tahap tercemar ringan yang dominan dengan nilai indeks pencemaran tertinggi dibandingkan pada kedua titik pengamatan yang lainnya karena dipengaruhi oleh aktifitas manusia dalam pemanfaatan lahan pertanian, wisata, dan pemukiman. Dari hasil penelitian bahwa akibat alih fungsi lahan dari hutan menjadi permukiman, mengakibatkan peningkatan debit aliran dan sedimentasi terutama pada saat musim hujan.

\section{Saran}

Perlu dilakukan sosialisasi kepada masyarakat yang bermukim di seputar permukiman relokasi tahap III Siosar secara berkesinambungan oleh pemerintah dan pengawasan serta dukungan mengenai tehnik pengelolaan kawasan yang baik serta konservasi tanah dan air. Untuk areal permukiman dalam menjaga kestabilan aliran permukaan air dapat dibuat lobang biofori, sumur resapan ataupun kolam resapan. Serta perlu diterapkan pengelolaan limbah yang baik dan dengan kebijakan melarang membuang sampah atau limbah ke lembah atau daerah aliras sungai.

\section{Daftar Pustaka}

[1] R. H. Anasiru dan Tilongkabila, "Perhitungan laju erosi metode usle untuk pengukuran nilai ekonomi ekologi di sub DAS Langge, Gorontalo," J. Pengkajian dan Pengembangan Teknologi Pertanian, Vol. 18, No. 3, 2015.

[2] W. Atima, 2015, BOD dan COD Sebagai Parameter Pencemaran Air dan Mutu Air Limbah. Jurnal Biology Science dan Education , 83-93, 2015.

[3] D. Aprilliyana, "Pengaruh perubahan penggunaan lahan sub das rawapening terhadap erosi dan sedimentasi Danau Rawapening," J. Pembangunan Wilayah \& Kota, Vol. 11, No. 1, Hal. 103$116,2015$.

[4] A. D. Ardi dan S. Rahayu, "Kajian kesesuaian perubahan penggunaan lahan terhadap arahan pemanfaatan fungsi kawasan Sub DAS Rawapening," Teknik PWK (Perencanaan Wilayah Kota), Vol. 2, No. 4, Hal. 958-967, 2013.

[5] C. Asdak, Hidrologi dan Pengelolaan Daerah Aliran Sungai. Yogyakarta: Gadjah Mada University Press, 2014.

[6] Balai Penelitian Tanah, Laporan Kinerja Balai Penelitian Tanah 2016. Balai Besar Litbang Sumber Daya Lahan Pertanian, Badan Penelitian dan Pengembangan Pertanian, Kementerian Pertanian, 2017.

[7] M. Djuwansah, "Status natrium pada tanah tercemar limbah Industri tekstil di Rancaekek, Kabupaten Bandung," J. Tanah dan Iklim, Vol. 37, No. 1, Hal. 25-34, 2013.

[8] Naryanto, H. S., Prihartanto, P., \& Ganesha, D. Kajian Kualitas Air Tanah dan Sungai pada Kawasan Rawan Banjir di Kabupaten Serang Kaitannya dengan Penyediaan Air Bersih. Jurnal Teknologi Lingkungan, 20(1), 45-56. 2019.

[9] Rantung, M. M., Binilang, A., Wuisan, E. M., \& Halim, F. Analisis Erosi dan Sedimentasi Lahan di Sub DAS Panasen Kabupaten Minahasa. Jurnal Sipil Statik, 1(5). 2013.

[10] Koesnandar, R.T. dan H. Sigit, Kajian Degradasi Lahan dan Air di Daerah Aliran Sungai Sengata, Kalimantan Timur. 2007. Diakses dari Jurnal fakultas Kehutanan.repository.ac.id, 31 Maret 2020.

[11] Rahmawati, D. Pengaruh Aktivitas Industri Terhadap Kualitas Air Sungai Diwak di Bergas 2831 
Kabupaten Semarang dan Upaya Pengendalian Pencemaran Air Sungai (Doctoral dissertation, Program Magister Ilmu Lingkungan). 2011.

[12] Rauf, A. Kajian Karakteristik Lahan Kawasan Relokasi Pengungsi Erupsi Gunung Sinabung Kabupaten Karo Sebagai Dasar Penggunaan Lahan Berbasis Pengelolaan DAS. Jurnal Pertanian Tropik, Vol. 2, No. 1 (8), 62-73. 2015.

[13] Soil Survey Staff, Kunci Taksonomi Tanah, Edisi Kedua Bahasa Indonesia, Pusat Penelitian Tanah dan Agroklimat, Badan Penelitian dan Pengembangan Pertanian, Bogor. 1998.

[14] Sucipto, Kajian Sedimentasi di Sungai Kali Garang dalam Upaya Pengelolaan DAS Kaligarang Semarang. Tesis Magister Ilmu Lingkungan Universitas Diponegoro. Semarang. 2008.

[15] Syawal, M S, Y Wardiatno dan S Hariyadi, Pengaruh Aktivitas Antropogenik Terhadap Kualitas Air, Sedimen dan Moluska di Danau Maninjau, Sumatera Barat. Jurnal Biologi Tropis, Januari2016: Volume 16 (1):1-14 ISSN:1411-9587. 2016.

[16] Keputusan Menteri Negara Lingkungan Hidup Nomor 115 Tahun 2003 Tentang Pedoman Penentuan Status Mutu Air.

[17] Peraturan Pemerintah Republik Indonesia No. 82 Tahun 2001 Tentang Pengelolaan Kualitas Air dan Pengendalian Pencemaran Air. 